\title{
The Green Value of Your Woods: A Summary of Ecosystem Services Provided by Forest Stewardship Lands in Florida ${ }^{1}$
}

\author{
Rose Godfrey, Chris Demers, Francisco Escobedo, Damian Adams, and Michael Andreu²
}

The Forest Stewardship Program (FSP) is a voluntary conservation program available to private landowners who own at least 20 acres. Administered by the Florida Forest Service, FSP provides assistance in developing a multiple-use forest management plan through site visits and technical assistance from forestry and natural resource professionals. Landowners enrolled in FSP manage their properties for a combination of wildlife management, timber management, livestock grazing, soil and water conservation, and recreation objectives. While these objectives provide direct benefits to landowners in terms of income and enjoyment, they also provide important benefits to society. Well managed forests provide a clean and abundant water supply, store carbon, and conserve wildlife habitat. These benefits that nature provides to society have been called ecosystem services.

Ecosystem Services are defined in the Stewardship Ecosystem Services Survey (SESS) project as the components of forests that are directly enjoyed, consumed, or used to produce specific, measurable human benefits. The (SESS) project identified ecosystem services of importance to both private landowners and public land managers, determined the types and amounts of ecosystem services provided by FSP lands in Florida, and calculated their economic value.
The SESS project focused on five ecosystem service studies and a survey on public managers' and private landowners' understanding of ecosystem services to calculate these values. The services analyzed in the study include nutrient retention, specifically nitrogen and phosphorus; water resource protection and forest conservation; carbon sequestration; timber production; and wildlife species conservation.

\section{Water Conservation}

Nutrient retention in forest soils benefits society by maintaining water quality. Excess nitrogen or phosphorus in the water can cause blooms of algae in springs and rivers, and potentially render water unsuitable for human and wildlife use. Water resource protection and conservation on FSP lands is also achieved by preventing soil erosion. The SESS study showed that FSP lands retain nutrients and soil particles more effectively when compared to non-FSP lands.

In order to quantify values for these types of services, the public's willingness-to-pay (WTP) for water quality protection programs was used. The public's WTP estimates how much an average Florida household would be willing to pay to support forest conservation programs that promote water quality. Not only are these services good for society, but the study shows that, in Florida, there is a cumulative WTP that ranges from $\$ 17$ million to $\$ 335$ million for conservation

1. This document is FOR313, one of a series of the School of Forest Resources and Conservation Department, UF/IFAS Extension. Original publication date September 2013. Visit the EDIS website at http://edis.ifas.ufl.edu.

2. Rose Godfrey, Extension assistant; Chris Demers, forest stewardship coordinator; Francisco Escobedo, associate professor; Damian Adams, associate professor; and Michael Andreu, associate professor; School of Forest Resources and Conservation, UF/IFAS Extension, Gainesville, FL 32611 
programs like FSP to protect water quality. In Florida, WTP values were higher for voluntary programs like FSP, which provide assistance to private landowners without public acquisition of property.

\section{Carbon Storage}

Carbon stocks were analyzed to quantify storage of carbon which might otherwise be released into the atmosphere and affect climate. USDA Forest Inventory and Analysis (FIA) data was used to estimate an average total value of carbon storage in four regions in Florida analyzed by the FIA. Carbon was also measured in dollar amounts per acre. The average total value of carbon stored on FSP land in all the four FIA regions in Florida ranged from $\$ 300,000$ to $\$ 578,000$ in average sized FSPs (237 acres for northwest and 395 acres for south Florida).

\section{Timber Production}

Timber production was considered an important management objective and included in the study. The timber valuations were reached using FIA data from the four Florida regions and an ecosystem services GIS model. Net merchantable growth was greater on FSPs in northeastern and southern Florida and ranged from 122 to $524 \mathrm{cuft} / \mathrm{ac} /$ year. In central Florida the net volume of growing stock for removal purposes was greatest on FSP lands compared to non FSP lands. Timber analysis results showed that there was no significant difference between FSP and non FSP management scenarios.

\section{Wildlife Conservation}

Wildlife conservation values were estimated using "nonconsumptive values," or how much people value wildlife existence and protection rather than "direct uses" such as hunting. The value of species conservation on private forest lands was estimated for five threatened or endangered wildlife species found on some FSP lands in Florida. The species included were the bald eagle, red-cockaded woodpecker, Florida black bear, gopher tortoise, and Florida scrub jay. The value estimates vary by the property location, what species live there, and the management plan in place. The estimated present value of FSP lands in terms of avoided wildlife population loss is approximately $\$ 54$ million. This means that $\$ 54$ million is expected to be saved by not converting wildlife habitat to another use that could be allocated for activities like wildlife-associated recreation.

\section{Conclusion}

Lands enrolled in voluntary forest management and conservation programs, like the Forest Stewardship Program, promote good land management practices. In addition to benefiting the landowners enrolled in these programs, good land management provides ecosystem services to society. The Stewardship Ecosystem Services Survey calculated the physical and economic benefits of water resource protection, carbon sequestration and storage, timber production, and wildlife conservation. The values reported in the study, and this summary, do not necessarily reflect the values that can be expected to be derived on a particular tract or ownership. The results should be viewed as a conservative estimate of ecosystem services and values provided by FSP lands across Florida.

\section{Reference}

Escobedo, F. and N. Timilsina (ed.). 2012. Final Report of the Stewardship Ecosystem Services Survey Project. Gainesville, FL: University of Florida. Full report available at http://www.sfrc.ufl.edu/CFEOR/ 